
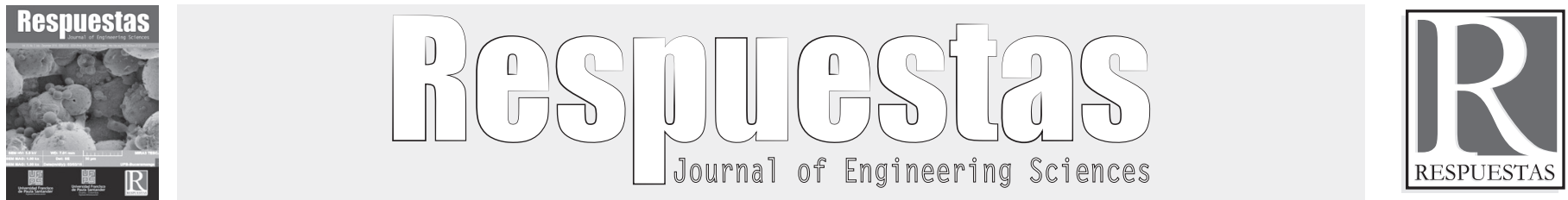

Original Article

https://doi.org/10.22463/0122820X.1681

\title{
Smart Tourism with Smart TVs
}

\section{Turismo inteligente con televisores inteligentes}

\author{
Luis Leonardo Camargo-Ariza ${ }^{1 *}$, Miguel José Rivera-Ospino², Byron Medina-Delgado ${ }^{3}$
}

${ }^{I^{*}}$ Magister en Ingeniería Electrónica, lcamargoa@unimagdalena.edu.co, Orcid: 0000-0002-7956-441X, Universidad del Magdalena, Santa Marta, Colombia. ${ }^{2}$ Magister en Administración de Empresas, gideam@unimagdalena.edu.co, Orcid: 0000-0001-5061-060, Universidad del Magdalena, Santa Marta, Colombia. ${ }^{3}$ Magister en Ingeniería Electrónica, byronmedina@ufps.edu.co, Orcid: 0000-0003-0754-8629, Universidad Francisco de Paula Santander, Cúcuta, Colombia.

How to cite: L.L. Camargo-Ariza, M.J. Rivera-Ospino and B. Medina-Delgado, "Smart Tourism with Smart TVs", Respuestas, vol. 23, no. 2, pp. 26-35, 2018.

Received on January 21, 2018 - Approved on June 12, 2018.

\begin{abstract}
\section{Keywords:}

Application software, information services, Santa Marta, smart devices, smart tourism.

The use of ICT to promote tourism in the Colombian Caribbean is limited; however, applications for smart TVs are a viable alternative due to their multimedia capabilities. This paper presents the development of an app called SantaMartaTV, which is intended for Smart TVs and envisions the concept of tourism in a Smart City. The app offers photos, videos, maps and descriptions of the most ideal touristic places in Santa Marta; it allows users to share the content on Facebook, a social networking site. The content displayed on the site is stored on XML files which contain information about the resources. These files are hosted in the servers of freely available services, such as Facebook, YouTube, Google Maps and Dropbox. This feature reduces the cost of implementing new technological infrastructure and facilitates the editing of content. SantaMartaTV promotes the good name of the city as well as improves the visitors' experience by providing them with interactive information at any time. This article further proposes a methodology for developing Smart TV apps. This new methodology is based on existing agile methodologies, usability concepts and the audiovisual capabilities of TV sets. The methodology satisfies the needs for the development of apps because it provides tools and diagrams which facilitate and guide the elaboration of these specific applications therefore ensuring a user-friendly and attractive app for potential users.
\end{abstract}

\section{RESUMEN}

\section{Palabras clave:}

Dispositivos inteligentes, Santa Marta, servicios de información, software de aplicación, turismo inteligente.
El uso de las TIC para promocionar el turismo en el caribe colombiano es limitado, las aplicaciones para televisores inteligentes es una alternativa debido a sus capacidades multimedia. El artículo muestra el desarrollo de SantaMartaTV, una aplicación creada para televisores inteligentes proyectando el concepto de turismo en una ciudad inteligente. La aplicación es capaz de mostrar fotografías, videos, mapas y descripciones de los sitios y eventos más representativos de la ciudad de Santa Marta; y permite a los usuarios compartir los sitios en la red social Facebook. Los contenidos mostrados son manejados a través de archivos XML que contienen la información sobre la ubicación de los recursos alojados en servidores gratuitos como Facebook, YouTube, Google Maps y Dropbox, reduciendo la implementación de infraestructura tecnológica y facilitando la modificación de los contenidos. SantaMartaTV hace posible la autopromoción de la ciudad y mejora la experiencia de los visitantes al tener acceso a la información en cualquier momento y de forma interactiva. Además, este artículo propone una metodología para la creación de aplicaciones en estos dispositivos, propuesta fundamentada en: las metodologías ágiles y cíclicas existentes, los conceptos de usabilidad y las capacidades audiovisuales de los televisores. La metodología planteada satisface las necesidades para el desarrollo de aplicaciones en televisores inteligentes, porque brinda herramientas y diagramas que facilitan y guían la elaboración de estas propuestas, asegurando aplicaciones de fácil manejo y de agrado para los usuarios. 


\section{Introduction}

Smart City is the modern concept of the ideal city, where economy, government, mobility, inhabitants, sustainability and environmental care function correctly and together in an intelligent symbiosis that improves people's quality of life [1]-[3]. This process is based on an adequate management of Information and Communication Technologies, ICT [4]; management that allows the participation of all actors for the construction of a better city, supporting decision-making in public administration and ensuring transparency and optimization in the execution of resources [5]-[6].

Intelligent tourism, which is inherited from the concept of intelligent city, has now been one of the most important issues in the tourism industry [7]. Intelligent tourism is defined as an urban tourism platform that integrates ICT, connecting tourism sources with technologies such as: artificial intelligence, cloud computing and the Internet of things, to provide explicit information and efficient services to tourists [8]-[9]. Intelligent tourism benefits the tourism industry and the travel industry in three ways: one, city information is integrated and centrally managed, this is convenient for tourists who require updated information and services; second, the use of monitoring devices in areas of interest allows real-time tracking of tourists, increasing demand for this area; and three, the intelligent tourism system provides an information exchange center [10]-[11].

An intelligent television is a television with computer capacity, operating system and connectivity, which allows: install and run own programs for the TV, in addition to connecting to the Internet to view multimedia content [12]. These devices turned the TV into an interactive information center, rethinking its use, through applications that execute predefined tasks in search of desired results [12]-[13]. According to Futuresource's report for 2018, 70\% of households will have an intelligent television and will use additional services to the conventional television in their television [14]. Currently there are applications for interactive digital television such as TripFromTV +, which offers customized tourist packages, and that influence the user to decide what to do and what to visit during a trip [15].

Cloud computing is a paradigm in which information is stored or processed permanently on Internet servers and eventually sent to temporary client caches, such as personal computers, smart phones, tablets and intelligent televisions, among other devices [16], allowing the consolidation of technological infrastructure in projects related to intelligent cities in an efficient manner, with quality of service and with a green infrastructure. Cloud computing offers different levels of architectures and models such as: IaaS, Infrastructure as a Service, PaaS, Platform as a Service, SaaS, Software as a Service, and BaaS or Mobile Backend, Background Services, among others.

BaaS is a tool to build robust and dynamic applications on any platform. In addition to providing storage capacity and information processing in the cloud, allows user management, push notifications, integration of social networks and other features that mobile users demand in their applications [17].

Santa Marta is a coastal city located in the Department of Magdalena in Colombia, a city that bases a large part of its economy on tourism. The government is currently developing projects to strengthen this economic sector and position the city as an international tourist destination [18]. Ecotourism is one of its greatest strengths, thanks to its ecological biodiversity [19]; historical and cultural tourism is also attractive because Santa Marta is one of the oldest cities in the Americas. These business models are those that want to be exploited in greater quantity with the use of new technologies.

The city is currently seeking to solve a wide variety of problems, in terms of civic works, security, health, education and economy [20]; if these development plans are successful and the city is restructured with the help of ICTs, Santa Marta would be close to becoming an intelligent city.

This work describes the development and evaluation 
of the SantaMartaTV application, an application that promotes the city and facilitates tourism, through televisions, using intelligent multimedia resources and Internet services without exceeding the limits established by companies such as Google and Facebook; through APIs developed under the BaaS approach.

\section{Materials and methods}

\section{Application Overview}

SantaMartaTV is an application developed for intelligent televisions, with the objective of promoting and strengthening tourism in the city of Santa Marta. The application shows photographs, videos, maps and a short description in English or Spanish of the beaches, historical places and significant events of the city (see Figure 1). In addition, it allows the user to share and comment on these places and events on the social network Facebook.

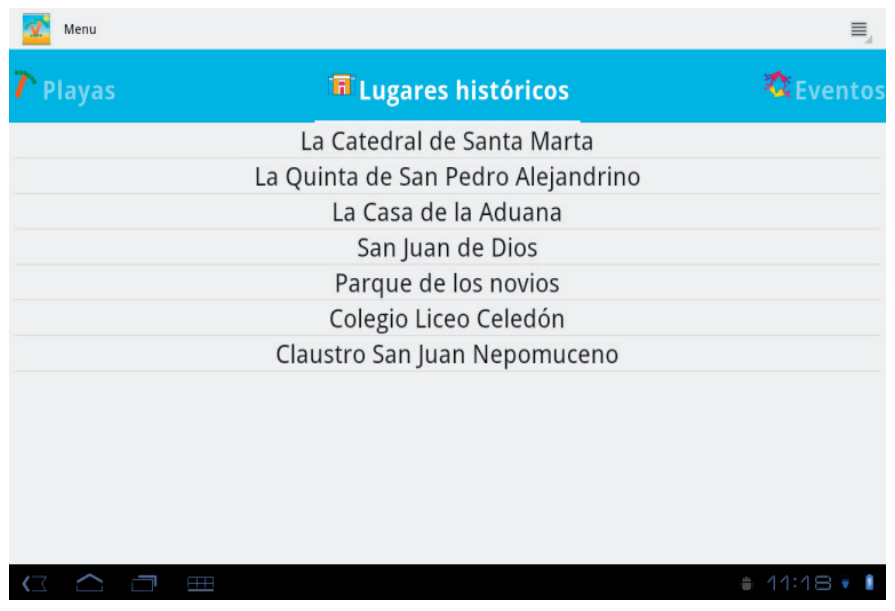

Figure 1. Application Category Menu

The content shown by the application is managed through XML files hosted in Dropbox, files that allow you to select and refer to text, elements, attributes and any other information contained in the file, such as the location of resources hosted on free servers on the Internet such as Facebook, YouTube and Google Maps, see Figure 2. This design aims to implement the application without a technological infrastructure of its own, such as Web servers and / or databases, also to facilitate the manipulation of the information displayed. com.google.android.youtube.player

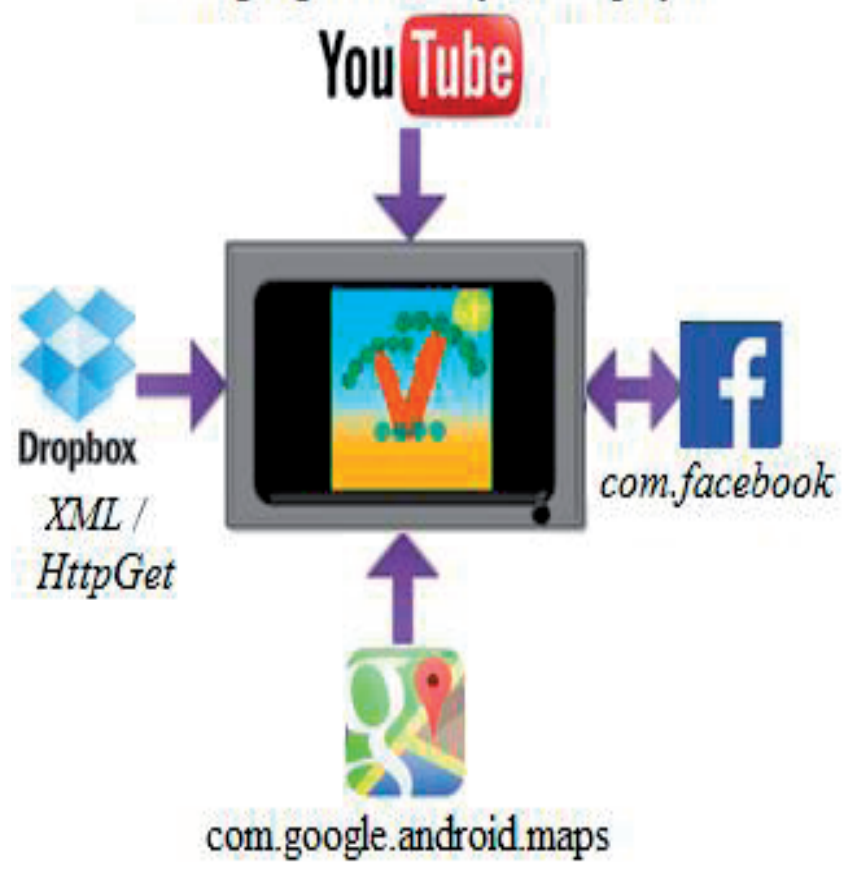

Figure 2. Scheme of integrated services a SantaMartaTV

The application is developed in Android for being a free platform with great penetration in the market of intelligent televisions; this operating system is used by brands such as Sony and also by small manufacturers such as Challenger, Olympus, Simply, Hyundai, among others.

\section{Methodology Design}

Smart TVs bring with them new challenges for developers, as they have different hardware and software characteristics to computers, tablets or smart phones; therefore the methodology for software development is adapted to the audiovisual potential of smart TVs. The main objective of this proposal is to facilitate the creation of applications, pleasant to the eye of the user and with a high degree of usability.

The methodology proposed and used in the development of SantaMartaTV is based on agile and cyclic methodologies for the development of software such as XP, Scrum and Crystal Clear, and on the requirements of ISO 9126 and 9421. Table I shows the comparison of the agile methodologies mentioned. 
Table I. Comparison between methodologies XP, Scrum y Crystal Clear

\begin{tabular}{|c|c|c|}
\hline $\mathbf{X P}$ & Scrum & Crystal Clear \\
\hline \multicolumn{3}{|c|}{ Stages or phases of the methodologies } \\
\hline - Analysis and exploration & - Future requirements & - Planning \\
\hline $\begin{array}{l}\text { (User History, Requirements; Exploration } \\
\text { Phase, Metaphors) }\end{array}$ & (List of requirements) & (Requirements, prioritization, schedule) \\
\hline - Planning & - Tasks of the sprint & - Feedback \\
\hline $\begin{array}{l}\text { (Order of implementation of stories, list of } \\
\text { specific tasks, delivery sched }\end{array}$ & (Iteration task list) & (Demonstration and retrospective) \\
\hline - Iteration & & - Implementation \\
\hline (Codification and customer participation) & $\begin{array}{l}\text { (graphics of work speed, Sprint 3-4 weeks, Revision } \\
\text { every } 24 \text { h) }\end{array}$ & (Design, coding, integration testing) \\
\hline $\begin{array}{c}\text { - Start of production } \\
\text { (Adjust while the user is using the devel- } \\
\text { oped software) }\end{array}$ & $\begin{array}{c}\text { - Iteration } \\
\text { (graphics of working speed, Sprint 3-4 weeks, } \\
\text { Revision every } 24 \mathrm{~h} \text { ) }\end{array}$ & $\begin{array}{l}\qquad \text { Tests } \\
\text { (Automation, functional, manual, regression) }\end{array}$ \\
\hline \multicolumn{3}{|c|}{ Some Similarities } \\
\hline & $\begin{array}{c}\text { Based on the values of the Agile ManifestoIteracione } \\
\text { - Frequent deliveries } \\
\text { - Direct contact with users } \\
\text { - Daily meetings meetings }\end{array}$ & \\
\hline \multicolumn{3}{|c|}{ Some Differences } \\
\hline - Short duration interactions (days) & - Interactions of medium duration (weeks) & - Interactions of medium duration (weeks) \\
\hline - The input is the stories of users & - The input is the stories of users & $\begin{array}{l}\text { - Project interviews. } 360 \text { degree exploration, re- } \\
\text { quirements, domains, models and technologies. }\end{array}$ \\
\hline - Couple Programming & - Individual work & - Side-by-side programming \\
\hline - Strictly follows the order of tasks & - You can change the order of tasks & $\begin{array}{l}\text { - Peace of mind and time to do the tasks and } \\
\text { constant communication with the director about } \\
\text { priorities. }\end{array}$ \\
\hline - Focuses on programming & - Focuses on the project & $\begin{array}{l}\text { - Look for small early triumphs and a not-so- } \\
\text { early victory. }\end{array}$ \\
\hline
\end{tabular}

The concepts of simplicity, flexibility, iterative and incremental development and continuous communication with the client were inherited from agile and cyclical methodologies [21]-[23]. From the ISO standards, the criteria of learnability, comprehensibility and operability were adopted, framed in the effectiveness, efficiency and satisfaction of software [24]-[26].

The main difference and contribution of the methodology is to strengthen, in the development process, the audiovisual design, taking into account the semantics (meaning and information) and aesthetics (signifier) of the system of signs used to improve the communication capacity of the application with the user. This strengthening will reflect a high degree of usability. Figure 3 shows the stages and activities of the methodology.

Estage 1, definition: This is the initial stage where the project guidelines are established through the three activities known as storytelling, achievement of objectives and allocation of resources.

Story: first meeting of the client or interested party with the work team, to identify the facts that describe the problem and possible solutions. In this activity the misinformation of the tourists about the city of Santa Marta was evidenced and the development of the application for intelligent televisions was proposed as a solution; highlighting the theoretical, technical and economic implications of the execution of the project.

Achievement of objectives: we define the course and the goals to be met in order to obtain the final product. SantaMartaTV aims to strengthen tourism in the city, using ICTs to provide multimedia information in English and Spanish about the most representative places, this information will be hosted on the Internet and updated by residents and visitors to the city. In addition, the contents will be managed by government entities using XML documents. 
Allocation of resources: the human resource, the necessary equipment and the software to be used are defined. In the project, a project leader, two developers and a graphic designer were assigned to the human resources; for the equipment an intelligent television with Android operating system, computer tools and Internet access; and for the software the development package for Android, the IDE compatible with Android and the social network development package.
The drafts of the application varied with each cycle, which lasted 1 month, due to the rethinking of the operating policies. The drafts were made using UML tools, such as diagrams of use cases (see Figure 4), sequence and classes, and additional mixed drafts were made in which they expressed how the graphic design should be and the interaction of the user with it.

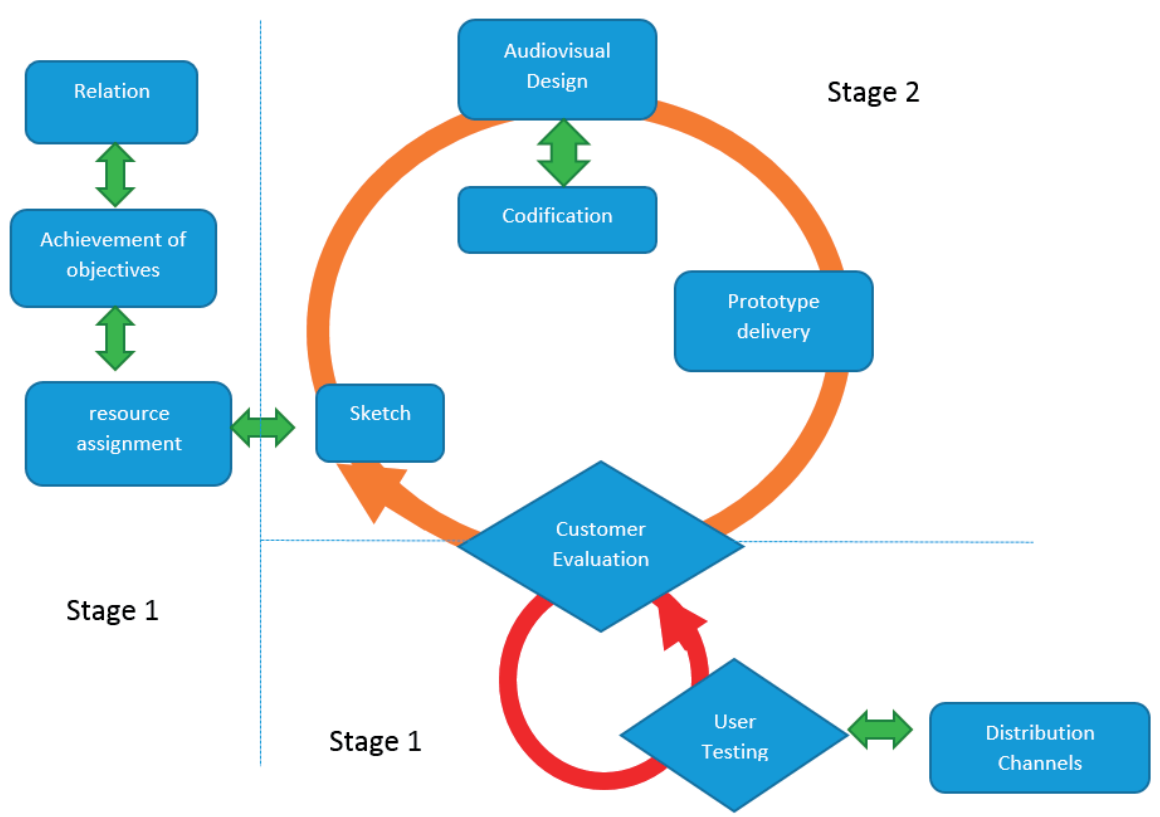

Figure 3. Diagram of the methodology

Stage 2, development: This stage has five activities, which are in a cycle, called sketching, coding, audiovisual design, delivery of the prototype and client evaluation; activities that convert the objectives into functional prototypes, which will be approved by the client when validating the fulfillment of the requirements and operability, by means of precision in the execution of the desired tasks.

Sketch: diagrams or sketches of the product are made, which serve as a guide for the coding and audiovisual design activities. This activity is carried out in each cycle or turn, solving the problems that arise in the following stages. The sketch takes into account the times, programming modules, technical limitations, graphic capabilities, ease of use and the operability of the software.

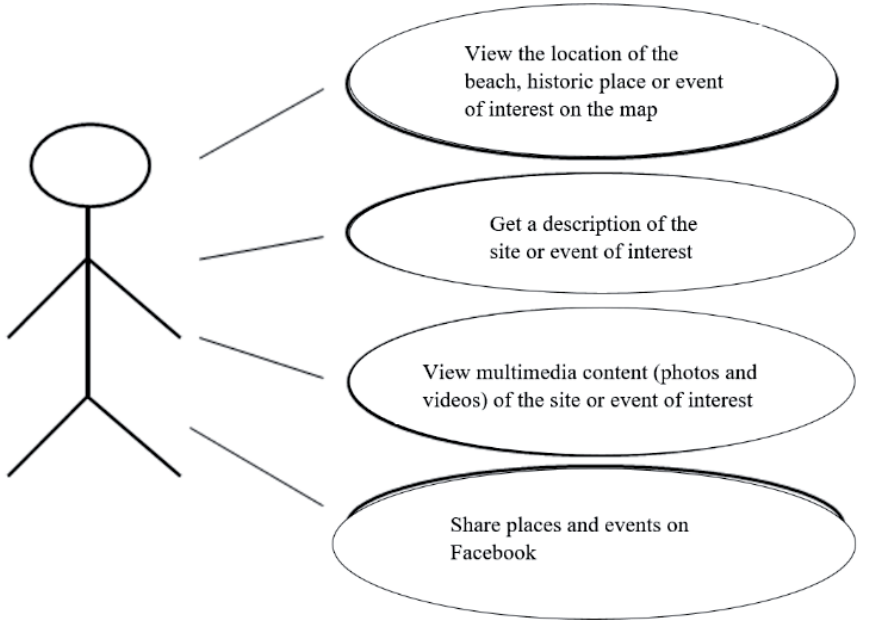

Figure 4. Application Usage Case Diagram

The sequence to arrive at the information of the desired place begins with the selection of the language, that reconfigures the application according to the 
language; then, the user enters the menu to select the place of interest, in this section the category and the site are chosen with the horizontal and vertical directional of the control, respectively (see Figure 1). Finally, the user reaches the screen with the desired content, which has a menu on the left to expand the information through videos, photos and maps and, to publish the place of interest on the Facebook timeline, see Figure 5. This sequence was designed considering a limited control when navigating on an intelligent television.

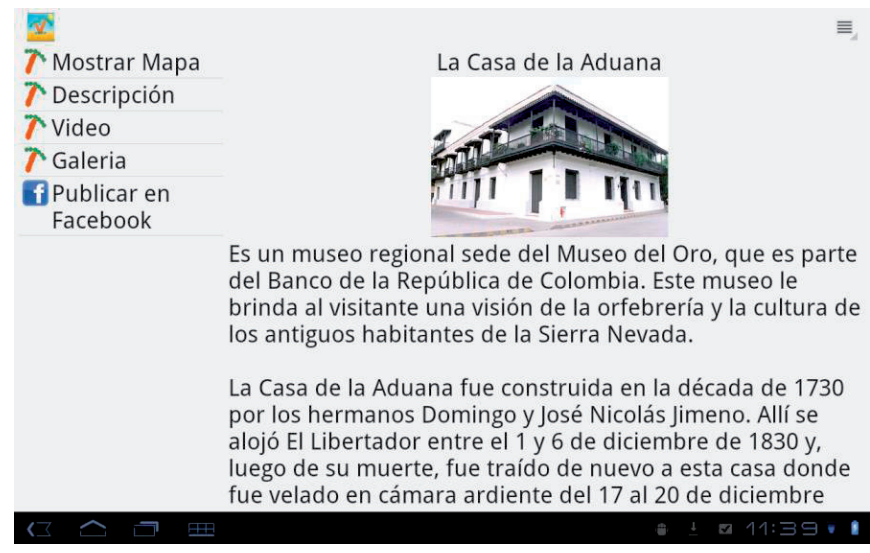

Figure 5. Description of a place in the application

Coding: each of the parts defined in the elaborated diagrams is written in the selected programming language. The application was made in Java language, with the IDE Eclipse; the tests of the code used a Jelly Bean distribution of Android for computers, installed in a virtual machine of the Oracle Virtual Box program having access to Google services, such as Google Maps (see Figure 6) and YouTube, among others, simulating a television with Android.

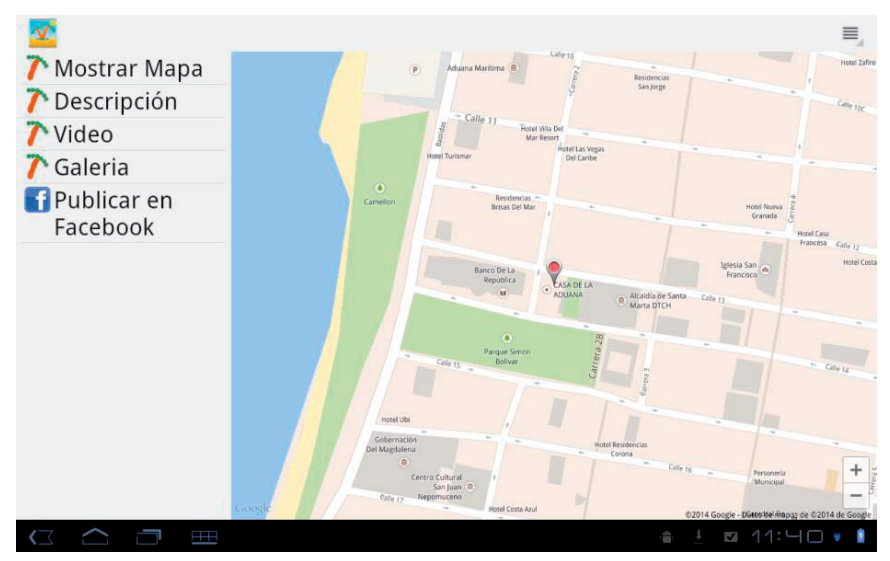

Figure 6. Location of a place in the application
Multiple free web services were used to manage Internet content. The videos use the YouTube development package for Android, the maps use the Google Maps development kit for Android, and the images are downloaded directly from the Blogger and Facebook. The XML files are stored in a public access folder in Dropbox, these files contain the description, the code of the videos, the coordinates of the site, the URLs of the images in the gallery and the link to share on Facebook, see Figure 7.

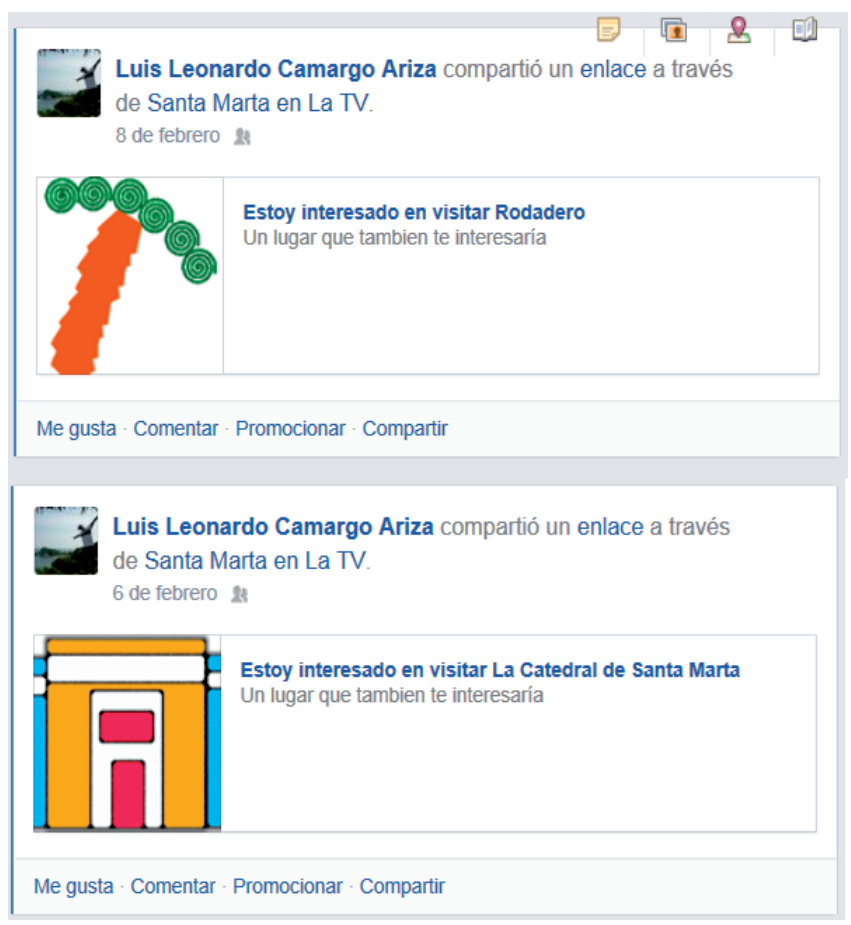

Figure 7. Example of Facebook publications

Audiovisual design: this activity is executed in parallel with the coding activity and its objective is to design the form and distribution (of the text, icons, symbols, sound effects and music) on the screens of the application, to ensure effective and pleasant communication with the user. The design of the application took into account: the average distance between the user and the television, to select the sizes of text and images; the sound effects and representative symbols in the menus; the division of the screen into frames to facilitate navigation and order of information; and the use of music representative of the city (The milk ice cream, musical history of Santa Marta). 
Delivery of the prototype: the coding and audiovisual design activities must culminate with a prototype that meets at least $30 \%$ of the client's requirements, including the missionary requirement. This prototype is not the final product and is delivered to the client for evaluation, in order to know the customer's appreciations and consider them in future prototypes.

Evaluation of the client: the client must send a response with the points against and in favor of the prototype, with the aim of feedback to the development team and thus obtain the final product.

When all the requirements are met and the human resource of the project considers that the application has been completed, we proceed to the stage of interaction with the users.

Stage 3, userinteraction: This stage has two activities called testing with users and distribution channels.

Tests with users: we interacted with people totally alien to the process of developing the final product, to get an idea of the acceptance that has the application in the community, prior to the start of distribution.

Distribution channels: once the application passes from the evaluation activity to the user population, it can be published in some distribution channel, such as manufacturers' application stores.

\section{Results and Discussion}

A day of use of the application was carried out, the population to which this day is directed are the potential users of the application, people totally alien to the process of elaboration; for being the very big population and the period of test according to the very short methodology, it was decided that this day would last five (5) days and two points were established to carry out the evaluation, the main seat of the University of Magdalena and the alternate seat of the university located in the center of the city. The volunteers who in this time and in these points carried out the test of the application comprise the sample, which has a size of fifty (50) volunteers, distributed between twenty-five (25) tourists and twenty-five (25) locals, with ages between 16 and 35 years. This sample is significant and sufficient to perform this type of black box testing according to [27] and [28].

Each volunteer, after interacting with the application for more than 20 minutes, evaluated the application. See Figure 8.

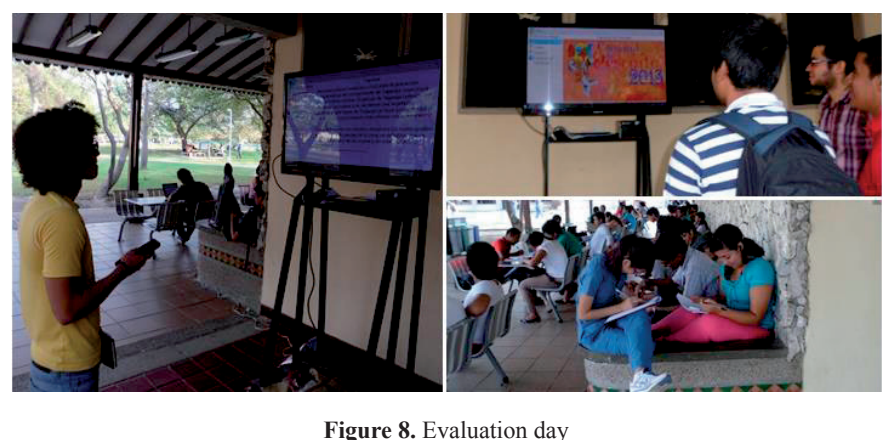

Usability heuristics was used to evaluate the application as an effective method to determine software quality [27]. Instead of proposing a new heuristic model, the method was used to evaluate interactive digital television, a method that focuses on 14 themes [28].

(H1) Match between the system and the real world

(H2) Simplicity

(H3) Consistency and standards

(H4) Feedback

(H5) Physical constraints

(H6) Extraordinary users

(H7) Structure of information

(H8) Navigation

(H9) Recognition rather than recall

(H10) Flexibility and efficiency of use

(H11) User control and freedom

(H12) Error prevention

(H13) Recovering from errors

(H14) Help and documentation

The applied instrument evaluated the 14 topics through 128 questions, on a scale of 1 to 10 . The 
answers were averaged for each question, scoring the question as a problem when the average was equal to or less than five. The results of this procedure yielded 21 of the 128 possible problems, see Figure 9. This allowed us to infer that the application has quality. did not show errors during the use of the application.

As a possible solution to the problems found in topic $\mathrm{H} 10$, it is recommended for higher versions of the application, that it evaluate the transfer speed and

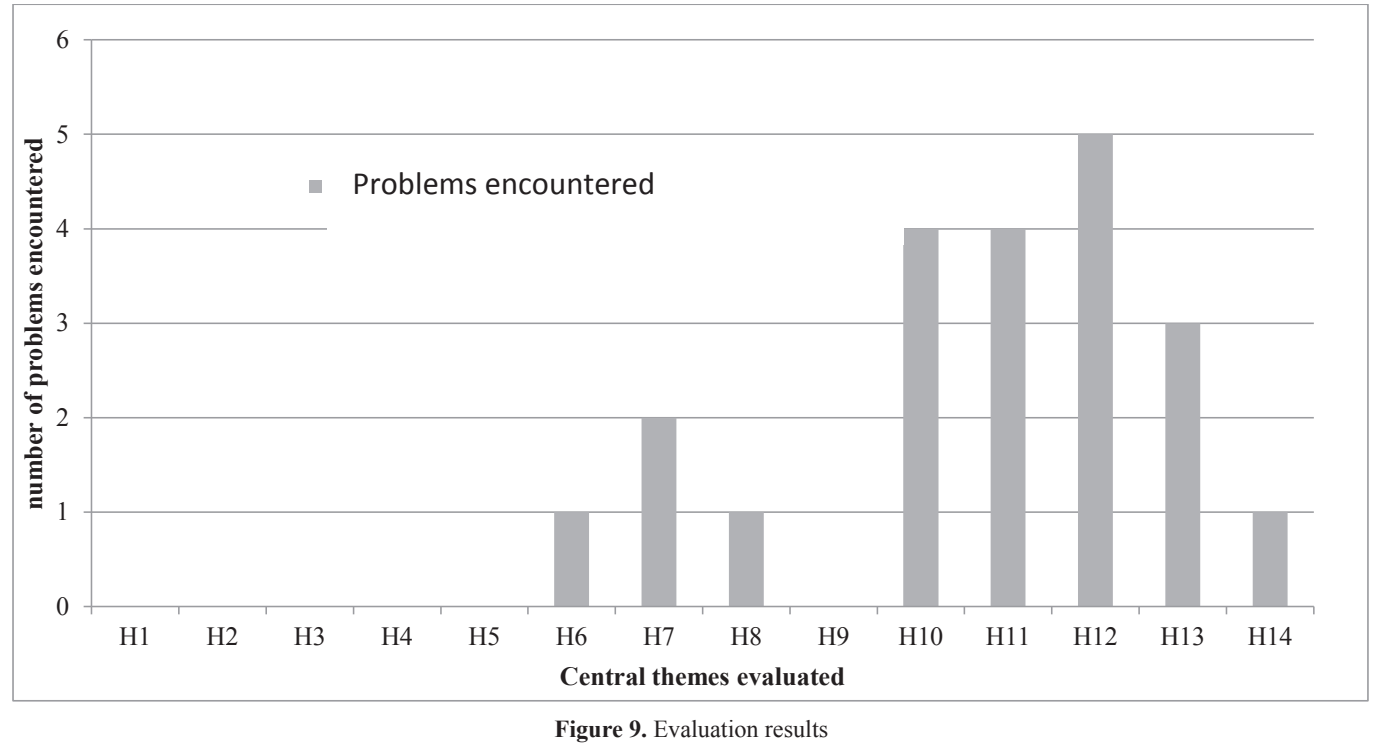

In the themes $\mathrm{H} 1, \mathrm{H} 2, \mathrm{H} 3, \mathrm{H} 4, \mathrm{H} 5$ and $\mathrm{H} 9$ no problems were detected. The most problems were found in themes H10, H11, H12 and H13.

The problems detected in H10, Flexibility and efficiency of use, were the result of a low data transfer rate on the network and the difficulty in validating the Facebook user using the TV control.

Problems were detected in H11, User control and freedom, because the application did not allow the user to manipulate the elements or processes of the application.

Problems were detected in the topic H12, Error prevention, because the application does not determine which situations can generate error, to warn the user before performing the action. The errors presented in the application are the result of problems with the Internet connection.

Problems were detected in H13, Recovering from errors, because the application does not have an error response mechanism, since the processes it performs do not have representative consequences on the application or the device. Additionally, many users tell the user if it is sufficient to ensure operational efficiency. According to the difficulty in validating the Facebook user, this is solved from the technological improvements of intelligent televisions with respect to the remote control.

As a possible solution to the problems found in topic $\mathrm{H} 11$, it is recommended for higher versions of the application that it allows the user to manipulate the graphical interface allowing the change of font and size, background, audio and order of lists.

As a possible solution to the problems found in topic $\mathrm{H} 12$, it is recommended for higher versions of the application that it evaluates the Internet connection and warns the user when it is lost.

As a possible solution to the problems found in the topic H13, it is recommended for higher versions of the application that it informs when the connection is lost and in the same way when it is recovered.

\section{Conclusions}

The proposed methodology satisfies the needs for the development of applications in intelligent 
televisions in a hundred per cent (100\%), because it provides tools and diagrams that facilitate and guide the elaboration of these proposals. In addition, it allowed to realize a quality deliverable product in the established time and with the participation of the client.

The evaluation method based on heuristics made it possible to detect learning, comprehension and operability problems in the applications.

The Android operating system was chosen to develop the SantaMartaTV application, because it is a free platform used by small manufacturers of intelligent televisions, with great market penetration, due to its low cost.

The development of the SantaMartaTV application, using libraries and development packages freely distributed by web services companies, to promote the use of their technological platforms, reduced the infrastructure required by the application to manage online content, such as documents, videos, photos and maps.

Tourism in an intelligent city requires interactive management of information, which allows users to be updated on the location and status of sites of interest in the city. For this reason, intelligent televisions are important to show contents in an interactive and agile way.

\section{References}

[1] P. Neirotti, A. de Marco, A.C. Cagliano, G. Mangano and F. Scorrano, "Current trends in Smart City initiatives: Some stylised facts," Cities, vol. 38, pp. 25-36, 2014.

[2] W.J. Mitchell, "Ciudades inteligentes," UOC Papers Revista sobre la sociedad del conocimiento, no. 5, pp. 1-11, 2007.

[3] R. Giffinger, C. Fertner, H. Kramar, E. Meijers, "City-ranking of European medium-sized cities," Centre of Regional Science, Vienna University of Technology, pp. 1-12, 2007.
[4] C. Harrison, et al., "Foundations for Smarter Cities," IBM Journal of Research \& Development, vol. 54, no. 4, pp. 1-16, 2010.

[5] C. Hafedh, et al., Understanding smart cities: An integrative framework. System Science (HICSS), 45th Hawaii International Conference On. IEEE, 2012. p. 2289-2297.

[6] S.Y. Velazco-Flórez and L. Joyanes-Aguilar, "Herramienta GIS y servicios web en la geolocalización como instrumento en la adecuada gestión del territorio: Geoportal IDE Chinácota," Respuestas, vol. 18, no. 1, pp. 5067, 2013.

[7] L.Y. Zhang, N. Li and M. Liu, "On the Basic Concept of Smart Tourism and Its Theoretical System", Tourism Tribune, no. 5, pp. 123-132, 2012.

[8] D. Wang, X. Li and Y. Li, "China's 'smart tourism destination' initiative: A taste of the servicedominant logic", Journal Destin Mark Manage, vol. 2, no. 2, pp. 59-61, 2013.

[9] D. Buhalis and R. Law, "Progress in information technology and tourism management: 20 years on and 10 years after the Internet-The state of eTourism research", Tourism Management, vol. 29, no. 4, pp. 609-623, 2008.

[10] J. Yang, C. Ryan y L.Y. Zhang, "Social conflict in communities impacted by tourism", Tourism Management, vol. 35, pp. 82-93, 2012.

[11] S. Robledo-Giraldo, N.D. Duque-Méndez and J.I. Zuluaga-Giraldo, "Diffusion of products through social networks: a literature review using graph theory", Respuestas, vol. 18, no. 2, pp. 28-42, 2013.

[12] M. Fernández, "La Smart TV cambia la forma de ver la televisión", Behaviour \& Information Technology, vol. 194, pp. 42-44, 2013.

[13] H. Choi, et al., "An empirical study on the adoption of information appliances with a focus on interactive TV", Telematics and Informatics, vol. 20, no 2, pp. 161- 183, 2003. 
[14] "TV Brands Rethink Content Strategies, 2014" Futuresource Consulting Ltd. Smart TV Sales Skyrocket, 2015. [Online] Available: http:// www. futuresource-consulting.com/201411-Smart- TV-Press-Release-8347.html. [Accessed: 5-dec-2015]

[15] Y. Blanco-Fernández, M. López-Nores, J.J. Pazos-Arias, J. García-Duque and M.I. Martín-Vicente, "TripFromTV +: Targeting Personalized Tourism to Interactive Digital TV Viewers by Social Networking and Semantic Reasoning”, IEEE Transactions on Consumer Electronics, vol. 57, no. 2, pp. 953-961, 2011.

[16] A. Yanuarizki, et al., "Toward cloud computing reference architecture: Cloud service management perspective" in International Conference on ICT for Smart Society (ICISS), Jakarta, 2013, pp. 1-4.

[17] S. Sravish, "Mobile Cloud Backend as a Service Ecosystem Map-All roads lead to BaaS", 2012. [Online]. Available http://www. kinvey.com/blog/65/mobile-cloud-backendasa-serviceecosystem-map-8211-all-roads-leadto-baas. [Accessed: 3-apr-2017]

[18] Alcaldía de Santa Marta, "Santa Marta-2012 Estado de Avance de los Objetivos de Desarrollo del Milenio", Codice, Bogotá, Colombia 2012.

[19] Ministerio de Comercio, "Turismo: factor de prosperidad para Colombia" Bogotá, Colombia, 2014.

[20] Alcaldía de Santa Marta, "Plan de Desarrollo 2012-2015 Alcaldía Distrital de Santa Marta, Un Hogar para la Vida", Santa Marta, Colombia, 2012.

[21] K. Beck, et al., "The Agile Alliance. Manifesto for Agile Software Development", site design and artwork (c) 2001, Ward Cunningham. [Online]. Available: http://agilemanifesto.org/.v [Accessed: 13-jun-2017]

[22] Scrum Alliance "Scrum: the basics". [Online]. Available: http://www.scrumalliance.org/pages/ what_is_scrum. [Accessed: 28-mar-2012]
[23] K. Beck and C. Andres, Extreme Programming Explained: Embrace Change, Addison Wesley, Stoughton, 2004.

[24] Software Engineering Product Quality, International Organization for Standardization ISO/IEC 9126, 1993.

[25] M. Bertoa and A. Vallecillo, "Medidas de Usabilidad de Componentes Software", IEEE Latin America Transactions, vol. 4, no. 2, pp. 136-143, 2006.

[26] Ergonomics of human-system interaction, International Organization for Standardization ISO/IEC 9241, 1999.

[27] E. K1lıç Delice and Z. Güngör, "The usability analysis with heuristic evaluation and analytic hierarchy process", International Journal of Industrial Ergonomics, vol. 39, no. 6, pp. 934939, 2009.

[28] A. Solano, C. Rusu, C. Collazos, and J. Arciniegas, "Evaluating interactive digital television applications through usability heuristics", Ingeniare Revista Chilena de Ingeniería, vol. 21, no. 1, pp. 16-29, 2013. 